Florida State University College of Law

Scholarship Repository

Scholarly Publications

1999

\title{
The Potential and the Pitfalls of Habitat Conservation Planning Under the Endangered Species Act
}

\author{
Shi-Ling Hsu \\ Florida State University College of Law
}

Follow this and additional works at: https://ir.law.fsu.edu/articles

Part of the Animal Law Commons, and the Environmental Law Commons

\section{Recommended Citation}

Shi-Ling Hsu, The Potential and the Pitfalls of Habitat Conservation Planning Under the Endangered Species Act, 29 ENVTL. L. REP. 10592 (1999),

Available at: https://ir.law.fsu.edu/articles/511

This Article is brought to you for free and open access by Scholarship Repository. It has been accepted for inclusion in Scholarly Publications by an authorized administrator of Scholarship Repository. For more information, please contact efarrell@law.fsu.edu. 


\title{
The Potential and the Pitfalls of Habitat Conservation Planning Under the Endangered Species Act
}

\begin{abstract}
Shi-Ling Hsu
Editors' Summary: The ESA is simultaneously the most popular and most hated of environmental statutes. Conservationists fervently support the ESA's mission of preventing the extinction of our country's fish, wildlife, and plants, but private landowners subject to ESA restrictions claim that the Act unfairly and illogically restricts the use of their valuable property. As the agency with primary responsibility for the ESA's administration, the U.S. Fish and Wildlife Service (FWS) is caught between both sides. This Article examines how the FWS uses habitat conservation plans (HCPs) to balance the demands of conservationists and property owners. The Article begins by discussing the divide between conservationists and property owners. It then describes how the Republican majority in Congress, the judicial trend in takings jurisprudence, and the ESA enforcement difficulties faced by the FWS have led to the increased use of HCPs. The Article next examines the appeal, effectiveness, advantages, and disadvantages of HCPs. The Article then explains how the trend in takings jurisprudence jeopardizes the continued legality and use of HCPs. Last, the Article concludes that the FWS should push for an ESA reauthorization bill that includes certain benefits for landowners as incentives for conservation. Without such a bill, the Article argues that the HCP process will be subject to political whimsy and judicial attack.
\end{abstract}

Shi-Ling Hsu is a Senior Attorney and Economist at the Environmental Law Institute. Mr. Hsu is a graduate of Columbia Law School, and he received his Ph.D. in Agricultural and Resources Economics from the University of California at Davis. Mr. Hsu was an Associate at Fenwick \& West in Palo Alto, California, from 1987 to 1989 and at Folger, Levin \& Kahn in San Francisco, California, from 1989 to 1990 . He was also a Deputy City Attorney for the city and county of San Francisco from 1990 to 1992. The author would like to thank Jim McElfish, Glenn Sugameli, Rick Gooch, Dennis Mackey, Cynthia Dohner, Sybil Vosler, Scott Spaulding, Michael Bean, Russ Henly, and Marca Weinberg for their assistance with this Article.

\section{[29 ELR 10592]}

The controversy surrounding the Endangered Species Act (ESA) of $1973_{-}^{1}$ always seems to bring out the most vociferous of critics and supporters of the Act. The debates on the ESA have often been quite ugly, and the public protests and counter-protests have often been violent. Like a referee in a professional wrestling match, the U.S. Fish and Wildlife Service (FWS), the agency with primary responsibility for the administration of the Act, ${ }_{-}^{2}$ has found itself trying its hapless best to keep the opposing sides from running amok with righteousness. In struggling to find a middle ground, the FWS has happily rediscovered the regulatory tool of habitat conservation planning, a statutory means by which a compromise is struck between landowners subject to potential ESA restrictions and the FWS, as guardian of endangered species. The FWS has now reached agreement with landowners on hundreds of deals allowing some destruction of habitat for species that are protected by the Act, in exchange for some promise on the part of the landowner to otherwise manage their property for the benefit of endangered species.

Virtually every federal environmental law in the United States has faced some form of opposition, but the ESA seems to have garnered more than its share of enemies. While opposition to other environmental laws, such as the Clean Air Act (CAA) ${ }_{-}^{3}$ the Federal Water Pollution Control Act (FWPCA) ${ }_{-}^{4}$ and the Comprehensive Environmental Response, Compensation, and Liability Act,,$_{-}^{5}$ has been at times - and continue to be - bitter and vocal, the general aims of these laws still enjoy broad public support. Historically, the political and legal battles over these laws seem to pit public health and safety against industrial interests, with the result being that supporters of these laws have seized the upper hand in terms of public opinion. There are signs, however, that trouble lies ahead as some of these laws threaten to inconvenience a broader population. The true tests of these laws probably lie ahead as broader and more powerful interests are affected. ${ }_{-}$

\section{[29 ELR 10593]}

The ESA, on the other hand, has always lived on the edge. From the beginning, there was a perception that saving species meant losing jobs in the timber industry, ${ }_{-}^{7}$ forbidding individual landowners to build on their land, and forcing small ranches and farms to cease operation. ${ }_{-}^{8}$ Opponents of the ESA have adroitly projected this fear onto a much 
broader population by convincing many that the ESA is a threat to that which Americans hold dear: their private property. The ESA's powerful prohibitions against the "take" of species listed as endangered or threatened do, in fact, extend to private property ${ }_{-}^{9}$ and even prohibit private landowners from engaging in actions on their property that adversely modify habitat of listed species. ${ }_{-}^{10}$ The fact that arguments for amending, reforming, or even repealing the ESA have a grain of truth in them has lent detractors an element of credibility and has generated considerable hostility toward the ESA. This hostility has manifested itself in political arenas throughout the history of the ESA and has increased in frequency and intensity of late. It has reached a point such that there is a constant threat of legislative overhaul of the ESA.

Proponents of the ESA have countered with their own equally powerful moral arguments that appeal to a different populace and a different ethic. The base of support for the ESA comes from the conservation community, those that argue for a moral imperative to preserve endangered species. The ESA has served as a beacon for the conservation community, a line in the sand that environmental organizations have steadfastly defended. In addition, the physical appeal of certain species protected by the ESA — the bald eagle, California condor, gray wolf, and grizzly bear, to name just a few of the "charismatic megafauna"11_ have proven to be a powerful lever for public opinion. For ESA proponents, strategies of drawing upon the inclination of people to protect attractive animals and warning people of the legacy that they leave behind for future generations have proven to be surprisingly effective.

In addition to the acrimony and political enmity fueled by vast differences in values, the ESA debate has also been driven by the ambiguity of takings jurisprudence. While few lawsuits have been filed that raise the claim that ESA restrictions work an unconstitutional taking of private property without just compensation, 12 the U.S. Supreme Court has muddled the relationship between land use regulation and constitutional protections of private property. The ESA has been a casualty of this ambiguity in that the FWS has operated under a chilling threat of a takings lawsuit. ${ }^{13}$ The problem is that the ESA straddles a distinction between regulations that prevent harm and regulations that confer benefits, the former being a legitimate exercise of the police power, and the latter being a constitutionally suspect attempt to extract benefits from a tyrannized few for a tyrannizing majority. While this distinction no longer has any legal significance, ${ }_{-} 14$ it still seems to have much influence in the court of public opinion and even among many commentators unacquainted with the nuances of takings jurisprudence. ${ }^{15}$ Another reason that the CAA and the FWPCA enjoy public support is that regulating the pollution of water and air seem to be harm-preventing exercises, but it is less clear whether regulations protecting biological diversity are harm-preventing or benefit-conferring. This has further polarized Americans with respect to the ESA.

The combination of the vituperative nature of the public debate and the constant threats of judicial and legislative challenges has sent the FWS scurrying for cover. Seeking not only to broker some peace between the warring sides, but also sensing that their regulatory authority was in the gunsights of ESA opponents, the FWS sought to extend landowners an olive branch. The FWS has thus resurrected the regulatory tool of habitat conservation planning, whereby the FWS will permit ESA violations in exchange for an agreement by a landowner to undertake mitigation measures that might not otherwise be required by law.

\section{The Legal and Political Context}

The ESA prohibits the "take" of any species listed as threatened or endangered by the FWS. The "take" of a species is defined to include not only the direct killing or capturing of [29 ELR 10594] listed species, but also a wide variety of actions that adversely affect listed species, such as harassment, ${ }_{-}^{16}$ pursuit, ${ }_{-}$and the alteration of habitat. ${ }_{-1}^{18}$ Moreover, as mentioned above, this prohibition applies to uses of private property. Therefore, private landowners may well find themselves unable to exploit their property as they see fit if their actions can be seen as an adverse alteration of habitat of a listed species. ${ }^{19}$ This application of the term "take" has spurred the most controversy surrounding the ESA because it highlights a property rights conflict between the rights of private landowners and the general rights of society, as expressed through the ESA, to biological resources and ecological integrity. It is hard to overstate the magnitude of this conflict because more than one-half of all endangered and threatened species have at least 81 percent of their habitat on private lands. 20

Enter habitat conservation plans (HCPs). The FWS may issue a landowner a permit to "incidentally take" endangered or threatened species if the landowner submits and agrees to abide by an FWS-approved HCP, which is a long-term plan of mitigation measures aimed at conserving habitat and aiding endangered and threatened species. The take of listed species must be "incidental to, and not the purpose of" an otherwise lawful activity. ${ }_{-}^{21}$ HCPs are an extra layer of regulation not intended to supersede any other state or local regulations. For example, before logging activities can take place in the old growth forested habitat of the threatened northern spotted owl, not only must an HCP be in place, but all other forestry permits required under state law must be obtained. Further, the HCP must not "appreciably reduce the likelihood of the survival and recovery of the species in the wild."22 HCPs represent a form of a regulatory compromise or, perhaps, pretrial settlement if one views litigation in the broader sense where possibly disastrous precedent could be set in ESA case law. HCPs allow landowners to realize some fraction of their development plans so that they can still garner private profits while allowing the FWS to implement some conservation measures where it might not otherwise be able. In addition, both parties avoid litigation costs, and both parties gain a measure of certainty that may be 
precious if they are at all risk-averse.

The HCP concept stemmed from an early ESA conflict involving the rare mission blue butterfly's only habitat, which is located in the San Bruno hills south of San Francisco. ${ }_{-}^{23}$ Potential ESA restrictions had jeopardized plans to develop private property within the butterfly's habitat, and local environmental groups had threatened to use the ESA's citizen suit provision to derail development plans. After seeking out local environmental groups and local governments interested in the development plans, the developer initiated and obtained a negotiated agreement regarding habitat preservation for the mission blue butterfly. The FWS, which also participated in the negotiations, gave the agreement its blessing and sought to amend the ESA to legitimize these types of negotiated solutions. The mission blue butterfly plan thus became the first HCP formally recognized under the ESA with the passage of 1982 amendments to the ESA. 24

The duration of HCPs have varied. Individual landowners desiring to construct a single-family home on their lot are often issued permits lasting five years, which is sufficient time for them to construct their house. Logging companies, on the other hand, that plan their harvests over long periods of time sometimes have HCPs lasting 100 years. ${ }_{-2}^{25}$ HCPs drew only modest interest in their earlier years, but experienced a dramatic upsurge in interest in 1994. From 1982 to 1989, only three HCPs were approved and only three incidental take permits were issued. From 1990 to 1993,22 HCPs were approved, but from 1994 to 1997, the number of HCPs skyrocketed to 193. As of January 31, 1998, the FWS had approved 230 HCPs. The upsurge in interest in HCPs has strained the FWS' resources, but citing a desire to engage in long-term, comprehensive, ecosystem-level planning, ${ }_{-}^{26}$ the FWS has embraced the HCP process. ${ }_{-}^{27}$ Affected landowners have also expressed enthusiasm for the $\mathrm{HCP}$ process, especially the increased regulatory certainty associated with HCPs. 28

While these positive-spin reasons for the upsurge in interest in HCPs are important, there are also other reasons. The increased popularity of HCPs coincided with the election of the 104th Congress, the first Congress since 1954 in which both the House and the Senate were governed by a Republican majority. The wave of reform-minded freshman Republicans adopted as part of their "Contract With America" legislative agenda a number of initiatives aimed at curbing federal regulatory powers, including takings legislation. Disappointed with the Supreme Court's reluctance to move takings jurisprudence quickly, property rights advocates proposed, and the Republican majority championed, takings [29 ELR 10595] legislation that would require federal regulatory agencies to compensate landowners if a federal regulation resulted in a diminution of property value that exceeded a threshold amount. ${ }_{-}^{29}$ Of course, requiring regulatory agencies to pay compensation for their regulatory actions would effectively terminate many regulatory programs, including the ESA, an outcome clearly envisioned by property rights advocates.

Some members of the 104th Congress also targeted the ESA specifically for legislative reform. A congressional Endangered Species Task Force was convened in order to hold a series of hearings throughout the country where input from landowners on possible ESA reforms could be solicited. These contrived hearings typically resembled a rally where most speakers expressed their bitter opposition to the ESA. ${ }_{-}^{30}$ Rep. Richard Pombo (R-Cal.), who chaired many of the hearings, was unapologetic about orchestrating the one-sided proceedings. In fact, Representative Pombo told reporters that the debate had been "stacked" the other way for years and that it was "their turn." 31 Meanwhile, back in Congress, the ESA was blamed for the downturn of the logging industry, the resulting psychological trauma experienced by timber industry workers, and even for child and spousal abuse in logging communities. ${ }^{32}$ Along with a flurry of other proposed laws reforming the ESA, ${ }_{-}^{33}$ Representative Pombo cosponsored legislation to do away with most of the ESA's mandatory provisions, limit the definition of "take" to the actual physical injuring of a species, limit the use of the citizen suit provision, and require the FWS to compensate landowners if any regulatory action resulted in any diminution of property value. ${ }^{34}$ Even legislation proposed by congressional supporters of the ESA contained some provisions that ESA opponents championed, such as a peer review process for any new listing decisions, ${ }^{35}$ and tax breaks for landowners entering into conservation agreements with the FWS. ${ }_{-}^{36}$ Although none of the ESA reform bills reached the floor of the House, some did pass the House Resources Committee, ${ }_{-}^{37}$ the mere fact of which was evidence enough that the ESA and the FWS were under fire. More tangibly, in 1995, Congress imposed a six-month moratorium on the listing of new species and the designation of new critical habitat. 38 Rather than directly forbidding the FWS from making any new listings or designations, the moratorium prohibited the FWS from using any of the appropriated funds for new listings or new critical habitat designations. Significantly, this was a strong signal that the Republican Congress might actually carry through with its threats to weaken the ESA, if only indirectly, but perhaps more effectively, by reducing FWS funding.

The upsurge in HCPs can also be explained by an increasing threat of unfavorable precedent being set in takings jurisprudence. While takings law has not yet made its indelible mark on the ESA, the threat seems real enough. Part of the impetus that induced the FWS to agree to purchase a 3,000-acre tract of old growth forest in northern California was the fact that the owner of the tract had filed a lawsuit in the Court of Federal Claims claiming that proposed ESA restrictions would amount to a regulatory taking in contravention of the Fifth Amendment of the U.S. Constitution. The deal, which involved the payment of $\$ 486$ million of state and federal money to a landowner with a reputation for poor environmental behavior, was roundly criticized by environmental organizations. ${ }^{39}$ However, the fact that the FWS was willing to engage in the effort to acquire the tract seems evidence enough of the threat posed by the lawsuit, which the 
landowner voluntarily dismissed as a condition of the purchase.

\section{[29 ELR 10596]}

With such hostility toward the ESA, it should perhaps be no surprise that the Act has a debilitating enforcement problem. When landowners become aware of the possible listing of a species that may affect their property, they sometimes preempt ESA restrictions by degrading their property so that it ceases to be a habitat. Numerous reports of "midnight bulldozing" just prior to the listing of the California coastal gnatcatcher indicated that developers were reacting to the possibility of land use restrictions interfering with their development plans. ${ }_{-}^{40}$ Some landowners simply kill the species just before it is listed. For example, prior to the listing of the San Diego mesa mint, one of the plant's three remaining populations was destroyed by a developer in order to avoid ESA restrictions. ${ }_{-}^{41}$ In other instances, even if ESA restrictions are in place, landowners will intentionally kill listed species they find on their property in the wellfounded belief that the FWS will never learn of the presence of the species or of the illegal act of killing them. Grizzly bears have been deliberately and quietly killed by ranchers fearful of losing their livestock to predation. . $^{42}$ Perhaps more than any other case, this has given rise to the phrase "shoot, shovel, and shut up." The extent to which such preemptive and sometimes illegal activity takes place is difficult to determine because the evidence is anecdotal in nature, ${ }_{-} 3$ but the abundance of such stories suggests that its occurrence is probably not unusual. Part of the problem is the political will on the part of the FWS to actually carry out the ESA's enforcement provisions. As recently as May 1998, a retired Arizona postal worker on a camping trip shot and killed one of a pair of endangered Mexican gray wolves that had been reintroduced at considerable taxpayer expense in a National Wildlife Refuge area. The only defense to the killing of an endangered species is self-defense, and protection of one's property is not a defense. ${ }_{-}^{44}$ Although the circumstances strongly suggested that the wolf posed no threat at all to the man or his dogs, the FWS declined to prosecute the man. .45

Another aspect to the FWS' enforcement problem is simply a lack of resources. Congress has traditionally refused to allocate the FWS sufficient funds to carry out a reasonable enforcement program. ${ }_{-} 6$ Thus, political will or not, the FWS has usually operated from a substantial disadvantage when attempting to deal with lawless landowners.

\section{The Response by the FWS}

With all the political hostility to the ESA, the threat of an unfavorable legal precedent, and the obstacles to enforcement, the FWS was in desperate need of engaging landowners in some form of voluntary compliance. It needed to do this not only to establish some positive relationship with landowners, but also to show the broader public that the ESA could be landowner friendly. Public relations had become a high priority for the FWS, and with HCPs, the FWS could make substantial overtures toward landowners. The FWS clearly welcomed a situation where they could "bargain in the shadow of the law," 47 rather than take their chances with the legislative or judicial branches.

The FWS manifested its commitment to HCPs not only by processing significantly more HCPs than they ever had in the past, but also by further sweetening the deal for landowners. In August 1994, the FWS introduced the "No Surprises" policy. Under the No Surprises policy, the FWS may grant an assurance that if a permittee fully complies with the terms of an HCP that adequately covers a species, the FWS will not require the permittee to undertake any further mitigation measures deemed necessary in the future. ${ }_{-}^{48}$ Further mitigation measures may be deemed necessary in the future if it is determined that a species' habitat needs are greater than previously thought, if previously absent listed species migrate onto the landowner's property, or if species not currently listed become listed and trigger a series of habitat protection regulations. A landowner with an HCP but without a No Surprises assurance may face additional regulations under those circumstances. A No Surprises assurance guarantees that the landowner's liability to undertake mitigation measures is limited to those set forth in the HCP. A No Surprises assurance will typically require the landowner to undertake additional mitigation measures in the short term, but landowners have not been hesitant to seize a guarantee that barring the occurrence of extraordinary circumstances, the HCP represents an exhaustive list of obligations with respect to the species covered by the HCP.

One question, however, remains. Have HCPs been an effective tool for addressing these problems?

\section{Criticisms and Praises of HCPs}

The criticisms of the HCP process are many. The most fundamental criticism is that HCPs allow the FWS to cede too much in the way of concessions to developers and loggers. The FWS has not used HCPs to aid in the recovery of listed species and has apparently settled for the more modest goal of only making sure that HCPs do not appreciably reduce the likelihood of survival and recovery of the species in the wild. ${ }^{49}$ In general, the FWS is criticized for implementing HCPs too generously by conceding to landowners far more than necessary in order to obtain their assent to an HCP. The evidence to support this assertion can be found in HCPs that seem to allow landowners to develop or log their property in substantially the same manner that they would in the absence of any ESA restrictions. Some HCPs for condominium construction in the beach dune habitat of the Alabama [29 ELR 10597] beach mouse require only that the condominiums be constructed north of the beachfront dune line, which is already required by state law. .50 In fact, 
the FWS was successfully sued by a Sierra Club chapter for the issuance of incidental take permits for the Alabama beach mouse without a sufficient scientific basis for determining that there would be "no significant impact." 11 Many HCPs for timber harvesting in the habitat of the Red Hills salamander only prohibit logging on land that the salamander is likely to occupy, which is land that is too steep to log anyway. ${ }_{-}{ }_{-}$Several HCPs for logging in the habitat of the red-cockaded woodpecker simply require that the permittee help to establish colonies of redcockaded woodpeckers by transporting woodpeckers to off-site locations where nesting cavities are drilled. One of the more shocking examples involves the Red Oak Timber Company of Louisiana, which purchased a 1,000-acre tract of forest land that provided habitat to two groups of redcockaded woodpeckers. After Red Oak logged all but the 137 acres of the land inhabited by the woodpeckers, it sought an incidental take permit to log the remaining acreage. Red Oak proposed an HCP that would relocate the woodpeckers to a nearby military base that had existing red-cockaded woodpecker habitat where artificial nesting cavities for the woodpeckers would be drilled. The total cost of these mitigation measures was $\$ 8,800$, approximately the amount of proceeds from the timber from five or six acres of the property. The FWS agreed. $\underline{53}$

It is premature to conclude, however, that this is simply a matter of the FWS giving away the store. Given the resources it has to work with, the FWS may simply be making the best of a bad situation. ${ }_{-}$The FWS has shown more vigor in negotiations involving land that is more ecologically valuable. In cases where the quality of the habitat is poor, the FWS will strike a more generous bargain with the landowner than it will when the habitat is of high quality. For example, the FWS has been more willing to permit development in the portions of Alabama beach mouse habitat that has been heavily developed than in those portions where the habitat is rich and important. 55

Some environmental organizations disenchanted with HCPs have suggested that the FWS has been "captured" by those interests that it is charged with regulating, namely developers and loggers. Political theorists argued several years ago that the Bureau of Land Management and the U.S. Forest Service seemed to be allying themselves with regulated parties rather than serving a broader public interest. 56 According to this theory, because federal officials at the local level interact with local regulated parties more often than anybody else, they are more likely to be swayed by their influence than by the influence of their superiors in Washington. Thus, the livestock, mining, and forest product industries appeared to wield undue influence in pushing these agencies toward managing for extractive uses of federal land. There is no evidence that the FWS has been captured, although cases such as the Red Oak Timber HCP are cause for some alarm.

The critical question is: what does the FWS consider to be its baseline from which it is negotiating? Since very few HCPs interfere substantially with development or logging plans, one could probably conclude that the FWS considers its bargaining position to be weak. Is this justified? At this point, the answer can only be based on anecdotal evidence. The case for the FWS being more aggressive in negotiations can be made by the Southwest Center for Biodiversity, a small Tucson, Arizona, environmental organization. Since 1993, the Southwest Center has sued federal agencies 113 times (mostly over ESA issues), and 79 percent of the time it has forced the agency to undertake the sought-after administrative action, such as the listing of a species or designation of critical habitat. ${ }_{-}^{77}$ With its meager budget, modest public relations efforts, and its opposition to powerful development interests, the Southwest Center certainly suffers from a number of disadvantages - at least as many as the FWS. Yet the fact that it has obtained a successful outcome 79 percent of the time suggests that the FWS may be overestimating the legal dangers of taking a more adversarial position. It would certainly seem that the Southwest Center is providing some significant legal cover for the FWS should it [29 ELR 10598] be interested in negotiating more aggressively. Litigation by environmental organizations opposing HCPs have heretofore been rare, ${ }_{-} 8$ but if the FWS continues to spend the majority of their time negotiating with potential permittees than with environmental organizations, past inaction by environmental groups will not likely continue.

A second fundamental criticism of the HCP process pertains to the very long-term commitments that are being made by the FWS. While it is true that logging companies in particular need to plan for time horizons on the order of 100 years, it is also true that much can happen in 100 years. Wetlands were not even considered ecologically valuable until several decades ago. What might the FWS be agreeing to give away that will be deemed highly valuable 50 years from now? This is an especially compelling question in forest HCPs, where the complexity of the ecosystem interactions are still only beginning to be understood. Thus, there is a good reason that forest HCPs are the only class of HCPs for which "No Surprises" assurances are not automatically attached to the HCP as a matter of FWS policy.

A third criticism of HCPs is that it has curbed citizen participation in the ESA. Citizen participation has been perhaps most beneficial in the case of the ESA because many listings of endangered or threatened species have been made pursuant to citizen petitions. Prof. Holly Doremus of the University of California Davis School of Law points out three ways in which citizens are effectively shut out of the HCP process: (1) the early negotiations of HCPs take place between the FWS and the landowner, with no public input; (2) too little information is provided to the public too late in the process; and (3) citizen suits are effectively undermined by the issuance of an incidental take permit that eliminates the possibility that a landowner is operating in violation of the ESA. ${ }^{59}$ This is a discouraging problem, especially because the high percentage success rate of the Southwest Center for Biodiversity suggests that there are many holes in ESA administration that are being left open by the FWS. 
A final criticism of HCPs is that the precedent set by the HCP process poses some gaming problems for federal regulators in general. The success regulated parties have had in forcing the FWS to the bargaining table by threatening to sue or lobby for legislative reform and by shooting, shoveling, and shutting up invites further intimidation. While we may hope that our regulatory agencies can persist in representing broader interests, in many cases they will not. Moreover, the mere threat of litigation or legislative attack, even if unmeritorious, imposes costs upon agencies that must evaluate the seriousness of each attack. The resources required to put out such fires would almost certainly be better spent carrying out its regulatory duties.

Not all the news is bad for HCPs. The HCP program has also attracted many advocates, the most prominent of which is Secretary of the Interior Bruce Babbitt. Secretary Babbitt has long sought to avoid thelogjam created by the litigation and political conflict over logging in the Pacific Northwest habitat of the northern spotted owl, which he characterized as a "national train wreck." 60 HCPs represented such an opportunity. They are a mechanism for the FWS and landowners to avoid litigation and its attendant costs, both in terms of resources spent and the uncertainty introduced into the regulatory process. Litigation is particularly ominous if, as is often the case in the ESA, the only possible outcomes for a parcel of private property are: (1) the FWS regulates the property, and (2) the FWS doesn't regulate the property. The most efficient outcome is likely to be one in which there is some development or logging and some preservation because it is a rare case where complete development or logging or complete preservation are the most desirable outcomes from a societal standpoint. Thus, HCPs allow the FWS and landowners to escape from a binary world where either the FWS or the landowner is a winner, and the other is a loser.

HCPs also offer the opportunity to perform planning on a regional or ecosystem level. California's Natural Community Conservation Program (NCCP), which is also meant to facilitate planning on a regional level, offered the Secretary a model that could be coopted into the HCP mechanism. Indeed, the pilot NCCP programs in the San Diego area and in Orange County, California, are hailed as examples of how comprehensive planning can be done at the regional level and with the input of developers, environmental organizations, community groups, and local, state, and federal government. ${ }^{61}$ Ideally, planning on a regional or ecosystem level for multiple affected species and with multiple stakeholders participating in the process allows for broader and more comprehensive ecological considerations and helps to avoid litigation, providing more certainty for all parties. A broader planning scale also allows for the identification of the best areas for development and the best areas for conservation. In addition, such comprehensive plans, if done well, can effectively delegate significant authority to local governments to carry out some of the more ministerial aspects of habitat management. ${ }^{62}$ The city of Austin, Texas, and the county of Travis, Texas, - where Austin is located — are authorized to issue permits for development in certain areas of golden-cheeked warbler habitat, provided that certain mitigation measures are agreed to by the landowners, many of whom are individuals seeking to construct single-family homes on a single lot. The city of Austin and Travis County must also contribute to the acquisition of some prime golden-cheeked warbler habitat in an area known as the Balcones Canyonlands. Multiple species and regional HCPs are also being developed in Las Vegas, Nevada; St. George, Utah; and Western Riverside County, California.

Perhaps the most compelling argument in favor of HCPs is that they allow the FWS to make the best of a bad situation. Apart from the unfortunate need to mollify its political enemies, the FWS must solve its "shoot, shovel, and shut up" problem. There are two aspects to the problem: one regarding illegal behavior and one regarding legal behavior, but both can be addressed by HCPs. With respect to the problem of deterring the illegal killing of species, HCPs serve as a means of ameliorating the FWS' enforcement problem. If the FWS cannot compel lawful observance of [29 ELR 10599] the ESA, perhaps it can induce landowners to agree to it. This seems an unfortunate necessary evil, but given the resources of the FWS, it may be necessary.

The other aspect of the FWS' "shoot, shovel, and shut up" problem is how to counter the incentives for legal behavior detrimental to imperiled species, such as the midnight bull-dozing that occurred prior to the listing of the California coastal gnatcatcher. HCPs by themselves cannot provide positive incentives to aid imperiled species that completely balance the negative incentives to harm imperiled species in the interests of avoiding ESA restrictions. However, the willingness of the FWS to negotiate HCPs tempers the possible downsides of managing private property in a speciesfriendly manner. HCPs also allow the FWS a means by which they can specify affirmative duties for the landowner where such duties could not be otherwise compelled. Ensuring that longleaf pine forests remain habitable for the redcockaded woodpecker requires several affirmative management measures, including prescribed burning and thinning and hardwood tree control. The threat by a North Carolina landowner to cease to manage his timberlands in such a fashion was part of the impetus for the FWS seeking out an HCP with the landowner. ${ }^{63}$ In addition, the FWS has incorporated into the HCP process the "Safe Harbor" policy, which protects landowners from future ESA regulation if they initially practice land management in such a way that is beneficial to listed species. This policy grew out of similar concerns of landowners that if their forest management practices were too beneficial to the red-cockaded woodpecker, their property would be colonized by woodpeckers and thereafter subject to ESA restrictions. ${ }_{-}^{64}$ In response to these landowners' concerns, the FWS proposed a special rule whereby the enhancement, restoration, or maintenance of habitat conducive to colonization or habitation of endangered or threatened species would insulate the landowner from future ESA restrictions, provided that if the landowner later abandoned species-friendly land management, the FWS would be afforded an opportunity to relocate the species. ${ }_{-} 6$ 
A final advantage of HCPs is that the FWS can obtain access to private property to gather much-needed information about endangered or threatened species. In the course of monitoring the population and the habits of the Alabama beach mouse, the FWS learned that the beach mouse utilized much more than the beach dunes previously thought to be its sole habitat. From the information gathered in these monitoring efforts, the FWS adjusted its HCP negotiating policy so that the HCPs also contained some measure of protection for the scrub dunes landward of the beach dunes. 66 Again, with more than one-half of all endangered and threatened species having at least 81 percent of their habitat on private lands, the FWS cannot allow itself to be shut out of private lands if it is to advance its knowledge of these species.

\section{The Specter of Nollan and Dolan}

Yet another threat looms for the FWS, and it may even affect the viability of the HCP program. Supreme Court takings jurisprudence may be moving at a pace disappointing to property rights advocates, but it has certainly not moved in a direction unfavorable to landowners. While the legal landscape is littered with takings cases that cloud the status of private property rights, two cases in particular, Nollan v. California Coastal Commission- ${ }_{-}^{67}$ and Dolan v. City of Tigard, 68 may pose problems for HCPs. These cases diverge from a substantial body of case law that has afforded regulatory agencies broad power to place conditions on the permitting of land use activities and imposed new tests upon the legitimacy of such conditions. ${ }^{69}$ Taken together, the cases require that any condition of a governmental issuance of a permit must bear a nexus with the underlying regulation or law that would authorize outright denial of the permit, and the condition must impose a burden on the landowner that is roughly proportional to the benefits conferred by the imposition of the condition. Since HCPs invariably contain a number of mitigation measures that could be considered conditions, these two cases pose threats to the authority of the FWS to negotiate HCPs at all.

The nexus requirement is a threat to HCPs because it is highly unclear whether a particular mitigation measure required by the FWS will be deemed by a court to be sufficiently related to the underlying statute, the ESA. For example, the FWS has often required the payment of money so it can acquire habitat to compensate for the loss of habitat on the property covered by the HCP. In the case of more than 40 HCPs for construction of single-family homes in the habitat of the golden-cheeked warbler, the payment of $\$ 1,500$ or $\$ 2,000$ is virtually the only thing that the FWS demanded of the landowner. The reason is sound enough - the FWS seeks to purchase prime golden-cheeked warbler habitat elsewhere. But does this invite the Supreme Court to ask whether such a payment scheme is only an "exercise in cleverness and imagination"? ${ }^{70}$ Money, after all, can be spent on anything. If unfavorable market conditions caused the FWS to be slightly remiss in acquiring mitigating property, courts will find that requirement of the payment of money to be a mere sham and lacking nexus to the preservation of endangered or threatened species.

The nexus requirement also poses problems for comprehensive, multi-species HCPs that provide mitigation measures for species not yet present on the property or not yet listed under the ESA. HCPs for timber harvest and management in the habitat of the northern spotted owl and the marbled murrelet sometimes involve hundreds of species other than the owl and the murrelet.. Does the possibility of a future migration onto the property or the possibility of a future listing provide a sufficient nexus to the ESA? It is hard to say. The problem is that little is known about the habits of many species. It would simply be impossible to say if a particular [29 ELR 10600] mitigation measure has any nexus to the goal of preserving species. Interestingly, it is typically the landowner that seeks to include more species in the HCP, rather than the FWS. It is apparently landowners that have more to gain from the inclusion of many species in an HCP. The nexus requirement also threatens HCPs that are aimed at study of imperiled species, such as adaptive management. ${ }^{72}$

Dolan's "rough proportionality" requirement may be even more disturbing. In addition to requiring that the condition impose a burden on the landowner that is roughly proportional to the benefits conferred, Dolan requires that "some sort of individualized determination" be made regarding the burdens and benefits of the conditions. ${ }^{73}$ While the recent Supreme Court decision in City of Monterey v. Del Monte Dunes at Monterey, Ltd. ${ }^{74}$ makes a point of confining the rough proportionality test to "excessive exactions" rather than outright denials of development, it has left unclear the scope of excessive exactions. ${ }_{-}^{75}$ Particularly troubling is the Supreme Court's remand of Ehrlich v. City of Culver City, ${ }_{-} 6$ the day after Dolan was decided, "for further consideration in light of" Dolan, and granting leave to the Pacific Legal Foundation, a property rights advocacy group, to file an amicus brief. The Ehrlich case involved the imposition of a development fee as a condition of approval of development, a condition commonly used in HCPs. Will such conditions undo HCPs, or does applicability of Dolan turn on whether the landowner is deprived of the right to exclude others from using the land for a public use? ${ }^{77}$ If that is the case, then the crucial advantage of HCPs allowing the FWS access to the property for biological study purposes may be eliminated.

Assuming that the rough proportionality test applies to HCPs, the critical question becomes: who is to say whether the burden imposed by a mitigation measure upon a landowner is roughly proportional to the benefits conferred? This is a question that even the FWS has trouble answering, and to allow the courts to second-guess the FWS is to invite trouble. HCPs for the Florida scrub jay are, for the most part, highly similar. Of the three remaining populations of the Florida scrub jay, one is broken down into a subpopulation existing on a barrier island and a subpopulation existing on an area on the mainland known as the Valkaria Preserve. Development pressure on the barrier island is intense, with 
vacant lots ranging in value from $\$ 30,000$ to $\$ 60,000$ per acre. This stands in contrast to the mainland, where vacant lots range in value from $\$ 4,000$ to $\$ 7,000$ per acre. The FWS has used this price differential to strike a compromise with developers seeking to build homes, condominiums, and resorts on the barrier island. In exchange for every acre of Florida scrub jay habitat lost to development, a developer must acquire two acres of Florida scrub jay habitat to augment the Valkaria Preserve. The FWS has thus made the decision to allow the barrier island to fall to the absolute minimum level necessary for that subpopulation to sustain itself — 19 families 78 — while focusing its recovery efforts on the mainland subpopulation by augmenting the Valkaria Preserve. Developers have found this exchange acceptable because their barrier island land is much more valuable than the mainland properties they are being asked to acquire, and the FWS seems to have made peace with pinning its recovery hopes on the mainland scrub jay subpopulation. Whether or not one believes that the FWS is doing a good enough job of negotiating, this arrangement, where valuable habitat and low-quality development land is exchanged for valuable development land and low-quality habitat, is the type of compromise that HCPs are most suitable for producing, and both sides improve their lot in the process. Yet who is to say that the two-for-one mitigation ration meets the rough proportionality test? Under the Dolan formulation, the burdens imposed by the mitigation condition- $\$ 4,000$ to $\$ 7,000$ per acre - must be roughly equivalent to the benefits conferred - the increased chances of survival for the mainland subpopulation produced by two additional acres of preserve. It is hard to imagine a judicial body undertaking such an inquiry, yet that is what the rough proportionality requirement would apparently call for.

There are other examples of mitigation measures that have the potential of running afoul of the rough proportionality test. As mentioned above, HCPs in the forested habitat of the northern spotted owl and the marbled murrelet are particularly complex. Most of the mitigation measures require the landowner to leave valuable trees standing. Suppose the burden imposed upon the landowner is measured in the foregone revenues of harvesting those trees. What is the significance of the fact that timber revenues vary substantially over time? Can a mitigation measure be roughly proportional to the habitat-providing benefits of preserving trees one year and not the next? Over 100 years, the answer to this question could very well be different.

Fundamentally, the problem is that little is known about many imperiled species. In the absence of such information, neither the nexus requirement nor the roughly proportional requirement can have any meaning.

\section{Conclusion}

While Prof. J.B. Ruhl $\_$asserts that the FWS was acting more proactively than defensively in ushering in the advent of HCPs, this initiative would not have occurred but for the FWS' enforcement problems and their political and legal problems. The FWS has long known that saving imperiled species requires the conservation of habitat on private property. What the Republican Revolution of 1994 highlighted [29 ELR 10601] was the political need to compromise in order to achieve some conservation measures on private lands. The Clinton Administration has clearly trumped property rights advocates on this issue by moving forward with a policy measure that meets with the approval of many landowners that face ESA restrictions.

But has the HCP initiative advanced the goals of the ESA? Prof. Karin Sheldon of Vermont Law School has argued that there is a continuing mismatch between the ESA's emphasis on individual species and the need to conduct habitat conservation planning on a geographic basis, with the result that HCPs are still awkward compromises that rarely contribute to a species' recovery. Professor Sheldon is also one of a number of commentators that has noted the apparent lenience with which the FWS has required mitigation measures in HCPs. While the FWS is not being consistently swindled by landowners, it would certainly appear that the FWS could stand to ask more of landowners for the valuable certainty of conducting operations free of worry over ESA violations. The preliminary litigation success by environmental organizations should provide some legal cover for the FWS and seems to indicate that the FWS would generally have the law on their side had they the political will to negotiate more aggressively. What the FWS probably fears is that if they did take a more aggressive position, the law would be changed in the form of dramatic ESA reform.

Granted, it is much easier to advise the FWS to drive a harder bargain than it is for them to actually do it. While the immediate risks posed by the 104th Congress have passed, many Republicans who were newcomers in 1994 are still in office, and Rep. Don Young (R-Alaska), who has made a political career from lambasting the ESA, is still the chair of the House Resources Committee. Moreover, an important reason that Representatives Young and Pombo failed in their efforts to bring about major ESA reform is because of the refusal of then-Speaker of the House Newt Gingrich (R-Ga.) to allow their versions of ESA to be brought before the full House of Representatives. ${ }^{80}$ No such obstacle exists in the current House. In this political climate, the FWS' best bet is to push for a reauthorization bill that is acceptable to enough Republicans to pass both houses. This may involve inclusion of certain benefits, such as tax incentives, for landowners that manage their land for habitat, and other mechanisms designed to remove perverse incentives to degrade habitat, such as Safe Harbor assurances, but this would also require that Congress abandon its traditional strategy of trying to choke the ESA to death by under-funding the FWS.

Congress' historical stinginess with respect to funding for ESA programs must be reversed. Opponents of the ESA had 
hoped to break the will of conservationists and the FWS by starving ESA programs, but it has been clear for a long time that this will not happen. The ESA is simply too important to too many environmental organizations, and too popular with the general public, for detractors to hope that it will wither away and die. Without adequate funding, however, the FWS cannot take enforcement actions against scofflaws. What could break the current stalemate is a combination of appropriations for ESA enforcement and positive incentives such as payments to induce landowners to act in the interests of imperiled species.

Perhaps little can be done in the short-term about the Nollan and Dolan doctrines. HCPs provide one of the more glaring examples of the pernicious effects of these cases. The Nollan and Dolan cases not only place undue emphasis on protecting the landowner, they place constraints upon the ability of both the FWS and the landowners to bargain. The yoke of the Nollan and Dolan doctrines move the ESA back toward a binary world in which a property is either regulated or not regulated, and mutual gains from exchange are lost. The best that the FWS can do is to remain vigilant about stating the biological bases for requiring mitigation measures in HCPs and hope for the best.

In an era where regulatory compromises and voluntary agreements ${ }_{-1}^{81}$ seem to be gaining popularity with both regulators and regulated parties, HCPs represent a compromise in an area of immense conflict. One can argue that the balance between landowners and the FWS has been struck incorrectly, but it is hard to argue with the HCP initiative's basic aims of avoiding costly and acrimonious litigation and planning for habitat conservation with more flexibility and more information. The FWS could do a better job of requiring help from landowners. Ultimately, however, where the HCP program goes from here may depend much more upon the courts and the legislature.

\section{16 U.S.C. $\S \S 1531-1544$, ELR STAT. ESA $\S \S 2-18$.}

2. The National Marine Fisheries Service has responsibility for administration of the Act as it applies to marine species, and the FWS has responsibility for all other species.

3. 42 U.S.C. $\S \S 7401-7671 q$, ELR STAT. CAA $\S \S 101-618$.

4. 33 U.S.C. $\S \S 1251-1387$, ELR STAT. FWPCA $\S \S 101-607$.

5. 42 U.S.C. $\S \S 9601-9675$, ELR STAT. CERCLA $\S \S 101-405$.

6. The FWPCA, commonly known as the Clean Water Act, may be thrust into a more delicate position by virtue of litigation. Environmental organizations have sued the U.S. Environmental Protection Agency (EPA) over its administration of FWPCA $\S 303(\mathrm{~b})$, which requires states to identify waters that do not meet state water quality standards and to develop plans to bring them into compliance. Because it is now understood that much water pollution emanates from disparate, nonspecific nonpoint sources, EPA may be forced to carry out provisions of the FWPCA that will affect larger and more powerful constituencies, such as farmers, loggers, ranchers, and developers. See Oliver A. Houck, TMDLs Ill: A New Framework for the Clean Water Act's Ambient Standards Program, 28 ELR 10415 (Aug. 1998); Oliver A. Houck, TMDLs: The Resurrection of Water Quality Standards-Based Regulation Under the Clean Water Act, 27 ELR 10329 (July 1997). The CAA, as well, is also being pushed into the limelight. In some states, air quality plans have involved new automobile inspection and maintenance plans that require automobile owners to undertake steps to ensure that their automobile is not unduly polluting the air; this may draw the ire of the average citizen.

7. Even President Bush used the ESA as a campaign point to win over western voters. Michael Wines, Bush, in Far West, Sides With Loggers, N.Y. TIMES, Sept. 15, 1992, at A25.

8. Rep. Richard Pombo (R-Cal.) testified before a Senate subcommittee as to the diminution in value of his own family's ranch caused by the designation of critical habitat of the San Joaquin kit fox. Endangered Species Act Reauthorization Hearings Before the Subcomm. on Clean Water, Fisheries, and Wildlife of the Senate Comm. on Env't and Public Works, 104th Cong. (1994) (testimony of Rep. Pombo). There was actually no designation of any critical habitat for the San Joaquin kit fox at the time of his testimony.

9. Babbitt v. Sweet Home Chapter of Communities for a Great Or., 115 S. Ct. 2407, 25 ELR 21194 (1995).

10. Id.

11. The flippant nickname given to species that are physically appealing to people. For a discussion of how the FWS has tended to spend more money on recovery of larger species, see Andrew Metrick \& Martin L. Weitzman. Patterns of Behavior in Endangered Species Preservation. 72 LAND ECON. 1-16 (1996).

12. The pertinent language of the Fifth Amendment to the U.S. Constitution reads: "nor shall private property be taken for public use without just compensation." U.S. CONST. amend. V. The large body of case law that has emerged in the past 20 years casts a shadow over many land use regulations that might be deemed to be onerous enough to be 
considered regulatory takings.

13. Barton H. Thompson, The Endangered Species Act: A Case Study in Takings and Incentives, 49 STAN. L. REV. 305, 306 (1997). Theories of how ESA regulation should be immune from regulatory takings challenges have been put forth, see, e.g., Oliver A. Houck, Why Do We Protect Endangered Species, and What Does That Say About Whether Restrictions on Private Property to Protect Them Constitute "Takings"?, 80 IOWA L. REV. 297 (1995); and Robert Meltz, Where the Wild Things Are: The Endangered Species Act and Private Property, 24 ENVTL. L. 369 (1994), but may not carry the day in the present Supreme Court.

14. Lucas v. South Carolina Coastal Council, 505 U.S. 1003, 22 ELR 21104 (1992).

15. See, e.g., Randy T. Simmons, Fixing the Endangered Species Act, 3 INDEP. REV. $511-36$ (1999). For an argument for resurrecting this distinction, see Lynda J. Oswald, The Role of the "Harm/Benefit" and "Average Reciprocity of Advantage" Rules in a Comprehensive Takings Analysis, 50 VAND. L. REV. 1449 (1997); and WILLIAM A.

FISCHEL, REGULATORY TAKINGS: LAW, ECONOMICS, AND POLITICS 354 (1995).

16. 16 U.S.C. $\S 1532(19)$, ELR STAT. ESA § 3(19).

17. Id.

18. Id. "Take" includes "harm" to the species and has been interpreted by federal courts to include alteration of habitat. Babbitt v. Sweet Home Chapter of Communities for a Great Or., 115 S. Ct. 2407, 25 ELR 21194 (1995).

19. Sweet Home, 115 S. Ct. at 2407, 25 ELR at 21194.

20. DAVID S. WILCOVE ET AL., REBUILDING THE ARK: TOWARD A MORE EFFECTIVE ENDANGERED SPECIES ACT FOR PRIVATE LAND (1996).

21. 16 U.S.C. $\S 1539(a)(1)(B)$, ELR STAT. ESA $\S 10(a)(1)(B)$.

22. Id. $\S 1539(\mathrm{a})(2)(\mathrm{B})(\mathrm{iv})$, ELR STAT. ESA $\S 10(\mathrm{a})(2)(\mathrm{B})(\mathrm{iv})$.

23. For a more detailed explanation of the events leading to the ESA amendment that includes HCPs, see MICHAEL J. BEAN, RECONCILING CONFLICTS UNDER THE ENDANGERED SPECIES ACT: THE HABITAT CONSERVATION PLANNING EXPERIENCE (1991).

24. Pub. L. No. 97-304, 96 Stat. 1411 (1982) (codified at 16 U.S.C. $§ 1533(b)(1)(A)$, ELR STAT. ESA $\S ~ 4(b)(1)(A))$.

25. See, e.g., MURRAY PACIFIC CORPORATION, AMENDMENT OF HABITAT CONSERVATION PLAN AND INCIDENTAL TAKE PERMIT PRT-777837 FOR THE NORTHERN SPOTTED OWL ON TIMBERLANDS OWNED BY THE MURRAY PACIFIC CORPORATION IN LEWIS COUNTY, WASHINGTON (1995) [hereinafter AMENDMENT OF HCP AND INCIDENTAL TAKE PERMIT].

26. J.B. Ruhl, While the Cat's Asleep: The Making of the "New" ESA, NAT. RESOURCES \& ENV'T, Winter 1998, at 187. Professor Ruhl notes that the FWS published several handbooks detailing the importance of preserving habitats instead of individual species. See, e.g., U.S. FWS, AN ECOSYSTEM APPROACH TO FISH AND WILDLIFE CONSERVATION: AN APPROACH TO MORE EFFECTIVELY CONSERVE THE NATION'S BIODIVERSITY (1994); U.S. FWS, PROTECTING AMERICA'S LIVING HERITAGE: A FAIR, COOPERATIVE AND

SCIENTIFICALLY SOUND APPROACH TO IMPROVING THE ENDANGERED SPECIES ACT (1995). Professor Ruhl characterizes the FWS' initiatives on habitat conservation planning as a part of a preemptive strike to change the way the ESA is administered to head off mounting criticism that the ESA is fundamentally unfair.

27. See, e.g., William E. Lehman, Reconciling Conflicts Through Habitat Conservation Planning, 20 ENDANGERED SPECIES BULL. 16-18 (1995).

28. See, e.g., John Wilkinson, Good News for Owls and Jobs, 20 ENDANGERED SPECIES BULL. 10-11 (1995).

29. See H.R. 29, 104th Cong. (1995), which called for compensation if diminution of property value exceeded 20 percent, and S. 605, 104th Cong. (1995), which would have required compensation if diminution exceeded 33 percent, but which also reached state regulations.

30. Nancy Vogel, Environmental Law Attacked-Foes Rip Endangered Species Act, SACRAMENTO BEE, Apr. 29, 1995, at 1; David Horsey, Greens on the Run: GOP Wave Threatens Environmental Regulations, SEATTLE POSTINTELLIGENCIER, Nov. 5, 1995, at E1.

31. Vogel, supra note 30. 
32. During debate on the ESA, Sen. Slade Gorton (R-Wash.) stated:

That preservation has wreaked incomprehensible havoc on timber families who have had to live with prolonged uncertainty about their futures. All indices of human despair have gone through the roof in these communities: child abuse, spousal abuse, alcohol and substance abuse, divorce, adolescent depression and suicide attempts, bankruptcies, and illness. All of these have been exacerbated by the terrible and unintended consequences of the Endangered Species Act of 1973.

138 CONG. REC. S16941 (daily ed. Oct. 5, 1992) (statement of Sen. Gorton).

33. There were a number of bills proposing substantial changes to the ESA. For example: H.R. 2253, sponsored by Rep. Robert Underwood (D-Guam), would have required the establishment of "community advisory boards," with which the FWS would be required to consult, wherever there is proposed critical habitat designation, or a proposed National Wildlife Refuge. H.R. 2253, 104th Cong. (1995). H.R. 1714, sponsored by Rep. Calvin Dooley (D-Cal.), would have required the FWS to conduct an annual review of listed species to determine if delisting was warranted. H.R. 1714, 104th Cong. (1995). H.R. 2364, sponsored by Rep. John Shadegg (R-Ariz.) would have replaced "no-take" provisions with voluntary participation plans and would have required the decision to list to be based "solely on the basis of independently verifiable data sufficient to reach a scientific conclusion, having that data verified by field testing to the extent practical." H.R. 2364, 104th Cong. (1995).

H.R. 2490, cosponsored by Reps. Billy Tauzin (R-La.) and Jack Fields (R-Tex.), would have required an external peer review before the listing of any new species and an economic impact statement with any designation of critical habitat and would have limited the citizen suit provision only to those suffering an "imminent or actual economic injury." H.R. 2490, 104th Cong. (1995), S. 768, sponsored by Sen. Slade Gorton (R-Wash.), which would have required peerreviewed research to be the basis for listing, would have excluded the alteration of habitat from the definition of "take" and would have limited the citizen suit provision to those who suffer an "imminent economic injury." S. 768, 104th Cong. (1995), S. 1152, introduced by Sen. Conrad Burns (R-Mont.), which would have exempted any state or federal wildlife management activities from the ESA unless there was an actual killing or wounding of a species. S. 1152, 104th Cong. (1995).

34. H.R. 2275, 104th Cong. (1995) (introduced as the Endangered Species Conservation and Management Act).

35. H.R. 2043, 103d Cong. (1993) (cosponsored by Reps. Gerry Studds (D-Mass.) and John Dingell (D-Mich.)).

36. H.R. 2351, 105th Cong. (1997) (sponsored by Rep. George Miller (D-Cal.)).

37. See, e.g., H.R. 2275, H. REP. NO. 104-778 (1996).

38. Omnibus Consolidated Rescissions and Appropriations Act of 1996, Pub. L. No. 104-134, 110 Stat. 1321.

39. The tract, located on the Northern California coast, is known as the Headwaters tract and is owned by the Pacific Lumber Company. Pacific Lumber is itself owned by Maxxam, Inc., which is owned by Houston financier Charles Hurwitz. See Joel Achenbach, Giants in the Earth, WASH, POST, Apr. 30, 1999, at A1. The deal was agreed to just minutes before the expiration of legislative authorization. William Booth, California, U.S. Buy Redwoods, WASH. POST, Mar. 3, 1999, at A1. The company even lost its state forestry license because of repeated violations of state logging practices. Patrick Hoge \& Nancy Vogel, Timber Firm License Lost: Headwaters Deal at Risk, SACRAMENTO BEE, Nov. 11, 1998, at A1.

40. Maria Newman \& Eric Bailey, Bulldozers Have Been Busy During Gnatcatcher Debate, L.A. TIMES, Aug. 1, 1991, at 1 .

41. Charles C. Mann \& Mark Plummer, Is the Endangered Species Act in Danger?, 267 SCIENCE 1256-58 (1995).

42. Charles McCoy, Sail-By Shootings Become a Problem in Monterey Bay-Sea Lions Are Among Victims of the Spiteful Violence Protectionism Has Spurred, WALL ST. J., Sept. 2, 1994, at A1.

43. John J. Fialka, Endangered Species Act, Itself Endangered, May Have Found the Political Backing to Survive, WALL ST. J., Mar. 2, 1998, at A20.

44. Christy v. Hodel, 857 F.2d 1324, 18 ELR 21430 (9th Cir. 1988).

45. Pete Bodo, Wolves' Walk on the Wild Side Proved Deadly, N.Y. TIMES, Apr. 25, 1999, § 8, at 9.

46. See, e.g., Nancy Kubasek et al., The Endangered Species Act: Time for a New Approach?, 24 ENVTL. L. 329-53 (1994); Robert D. Thomton, Searching for Consensus and Predictability: Habitat Conservating Planning Under the Endangered Species Act of 1973, 21 ENVTL. L. 605-49 (1991). 
48. Habitat Conservation Plan Assurances ("No Surprises") Rule, 63 Fed. Reg. 8859 (Feb. 23, 1998).

49. Karin L. Sheldon, Habitat Conservation Planning: Addressing the Achilles Heel of the Endangered Species Act, 6 N.Y.U. ENVTL. L.J. 279 (1998); Jon P. Tasso, Habitat Conservation Plans as Recovery Vehicles: Jump-Starting the Endangered Species Act, 16 U.C.L.A. J. ENVTL. L. \& POL'Y 297-318 (1999).

50. See, e.g., U.S. FWS, FINAL ENVIRONMENTAL ASSESSMENT ON THE ISSUANCE OF AN INCIDENTAL TAKE PERMIT FOR ALABAMA BEACH MOUSE PURSUANT TO SECTION 10(a)(1)(B) OF THE ENDANGERED SPECIES ACT TO HUNT PROPERTIES (1996). Alabama state law provides that no construction may occur north of the "Construction Control Line," which also happens to demarcate primary and secondary habitat from tertiary habitat of the Alabama beach mouse. ALA. ADMIN. CODE § 335-8-2-.08(1) (1995). Other modest mitigation measures are typically required, such as the implementation of a special outdoor lighting program to prevent disturbances to Alabama beach mice, a prohibition on cat ownership, and a requirement that any replanting be done with indigenous plants. Individuals with small lots seeking to build a single-family home, in particular, have received favorable consideration from the FWS.

51. Sierra Club v. Babbitt, 15 F. Supp. 2d 1274 (S.D. Ala. 1998).

52. See, e.g., Notice of Receipt of an Application, and Availability of an Environmental Assessment and Finding of No Significant Impact for an Incidental Take Permit for the Red Hills Salamander by Wilmon Timberlands for Forest Management in South Central Alabama, 62 Fed. Reg. 5032 (Feb. 3, 1997); Availability of Finding of No Significant Impact and Final Environmental Assessment and Receipt of an Application for an Incidental Take Permit for Timber Management Practices in Conecuh and Monroe Counties, Alabama, 58 Fed. Reg. 41291 (Aug. 3, 1993); Availability of an Environmental Assessment and Receipt of an Application for an Incidental Take Permit for Timber Management Practices in Conecuh and Monroe Counties, Alabama, by MacMillan Bloedel Timberlands, Inc., 61 Fed. Reg. 8301 (Mar. 4, 1996).

\section{WILCOVE ET AL., supra note 20.}

54. See, e.g, Shi-Ling Hsu, A Model of Environmental Compromise Between Regulators and Landowners Under the Endangered Species Act (1998) (unpublished Ph.D. dissertation, University of California at Davis) (on file with author). The dissertation examines individual HCPs and tests dual competing hypotheses as to whether the FWS or landowners are consistently appropriating the surplus from the HCP compromise process (if both parties enter into a compromise willingly, they must both be at least as well off than if they had failed to compromise). If the FWS is consistently appropriating the surplus from the HCP compromise process, then the terms of the HCP should vary with the profitability of the development project or logging plan. Conversely, if the landowners are consistently appropriating the surplus, the terms of the HCP should vary with the ecological value of the property. The rationale for these theoretical results is that whoever is appropriating the surplus is pushing the other party to the point at which they are indifferent between compromise and litigation. Thus, if the landowners are winning the negotiations, the FWS will allow more land to be developed if the land is not ecologically valuable, but less land to be developed if the land is ecologically valuable. In that sense, the terms of the HCP vary with the ecological value of the land. The empirical findings of the dissertation were, however, that the terms of the HCP were varying with both private value and ecological value, indicating that neither party was systematically appropriating the surplus.

55. Id. at 132-48.

56. See, e.g, PHILLIP FOSS, POLITICS AND GRASS (1960).

57. Telephone Interview by Shi-Ling Hsu with Kieran Suckling, founding Director. Southwest Center for Biodiversity (May 26, 1999).

58. It would appear to be foolhardy, however, for a developer to rely upon the lack of past litigation as an indication of future inaction as well. J.B. Ruhl, How to Kill Endangered Species, Legally: the Nuts and Bolts of Endangered Species Act "HCP" Permits for Real Estate Development. 5 ENVTL. LAW. 345-405 (1999).

59. Holly Doremus, Preserving Citizen Participation in the Era of Reinvention: The Endangered Species Act Example, 25 ECOLOGY L.Q. 707, 713-15 (1998).

60. Tom Kenworthy, Babbitt Clears Compromise to Protect California Bird, WASH. POST, Mar. 26, 1993 , at A2.

61. See, e.g., Marc J. Ebbin, Is the Southern California Approach to Conservation Succeeding?, 24 ECOLOGY L.Q. 695-706 (1997). 
62. Id.

63. U.S. DEP'T OF THE INTERIOR, FINDINGS AND RECOMMENDATIONS ON APPLICATION SUBMITTED BY MR. BEN CONE JR., FOR INCIDENTAL TAKE PERMIT FOR THE RED-COCKADED WOODPECKER ON HIS PROPERTIES CALLED CONE'S FOLLY AND THE LONG RIDGE TRACT, PENDER COUNTY, NORTH CAROLINA (1996).

64. WILCOVE ET AL., supra note 20.

65. Safe Harbor and Candidate Conservation Agreements, Proposed Rule, 62 Fed. Reg. 32189 (June 12, 1997).

66. Personal e-mail communication from Richard Gooch, Habitat Conservation Plan Coordinator, U.S. FWS Region 4, to Shi-Ling Hsu, Senior Attorney and Economist, Environmental Law Institute (Sept. 21, 1998) (on file with author).

67. 483 U.S. 825, 17 ELR 20918 (1987).

68. 512 U.S. 374, 24 ELR 21083 (1994).

69. Dana, supra note 47.

70. Nollan, 483 U.S. at 841,17 ELR at 20922.

71. See, e.g., WASHINGTON DEP'T OF NATURAL RESOURCES, FINAL HABITAT CONSERVATION PLAN (1997); see also AMENDMENT OF HCP AND INCIDENTAL TAKE PERMIT, supra note 25.

72. "Adaptive management" is a term used to describe a scheme whereby management actions and monitoring programs are updated constantly as ecological data is collected. This has been used most prominently in fisheries management. See, e.g., John M. Volkman \& Willis E. McConnaha, Through a Glass Darkly: Columbia River Salmon, The Endangered Species Act and Adaptive Management, 23 ENVTL. L. 1249 (1993). Adaptive management HCPs are similar to the one governing a timber harvesting plan proposed by the Weyer-haeuser Company and designed to allow study of the threatened American burying beetle. See Availability of an Environmental Assessment and Receipt of an Application for an Incidental Take Permit for the American Burying Beetle by Weyerhaeuser Company for Timber Harvesting and Management in Little River County, Arkansas, and McCurtain County, Oklahoma, 60 Fed. Reg. 63054 (Dec. 8, 1995).

73. Dolan, 512 U.S. at 391, 24 ELR at 21087.

74. 119 S. Ct. 1624, 29 ELR 21133 (1999).

75. See also Dana, supra note 47, at 1259.

76. 512 U.S. 1231 (1994) (mem.).

77. Clajon Prod. Corp. v. Petera. 70 F.3d 1566, 1578, 26 ELR 20213, 20218 (10th Cir. 1995).

78. U.S. FWS, BIOLOGICAL OPINION: GEN REAL ESTATE AND MANAGEMENT COMPANY (BAL HARBOUR SUBDIVISION) INCIDENTAL TAKE PERMIT IN BREVARD COUNTY, FLA. (1994).

79. Ruhl, supra note 26 .

80. Michael J. Bean, The Gingrich That Saved the ESA, ENVTL. F., Jan./Feb. 1999, at 26-32.

81. For example, EPA's 33/50 Program, whereby polluters may voluntarily reduce discharges of industrial toxic pollutants in order to stave off a legislative threat of more stringent future regulation. This program provides an interesting juxtaposition with the ESA case, since the legislative threat is being used as leverage by the regulator in the EPA program.

29 ELR 10592 | Environmental Law Reporter | copyright (C) 1999 | All rights reserved 